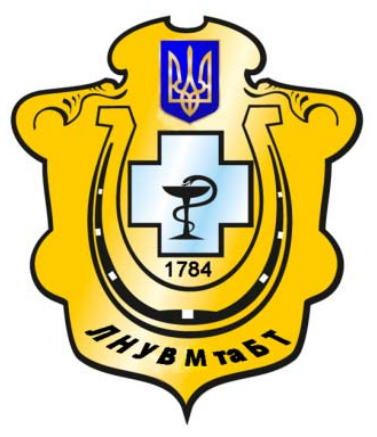

Науковий вісник Львівського національного університету ветеринарної медицини та біотехнологій імені С.3. Гжицького

Scientific Messenger of Lviv National University of Veterinary Medicine and Biotechnologies named after S.Z. Gzhytskyj

doi:10.15421/nvlvet6804

ISSN 2413-5550 print

ISSN $2518-1327$ online

$\underline{\text { http://nvlvet.com.ua/ }}$

УДК 664.9(075)

\title{
Використання нізину у виробництві варених ковбас фунціонального спрямування
}

\author{
В.В. Власенко, І.Г. Власенко \\ vlasenkovanya@mail.ru
}

Вінницький торговельно-економічний інститут Київського національного торговельно-економічного університету, вул. Соборна, 70, м. Вінниця, 21050 Україна

Сьогодні на украӥнському ринку фігуруе понад 300 найменувань ковбасних виробів, але велика увага приділяється створенню новітніх технологій виробництва харчових продуктів, зокрема продуктів, які отримали назву - функиіональні продукти харчування. Технологї виробництва функиіональних варених ковбас Діабетична призначена для людей, щэо страждають иукровою хворобою (діабетом) $і$ посвячена наша робота. При виробництві варених ковбас використовують нітрит натрію або калію. 3 а рішенням ВООЗ добова доза для людини має складати не більш 5 мг на 1 кг маси тіла. Небезпека використання нітритів полягає в тім, що саме вторинні аміни здатні реагувати з нітритами ковбас, утворюючи нітрозаміни. Нітрозаміни відносяться до сильнодіючих токсичних речовин, які негативно впливають в першу чергу на печінку та нирки людини в результаті чого відбувається порушення їх функцій та некрози. Однак найбільшу небезпеку для організму людини становить канцерогенна дія нітрозамінів, які можуть викликати утворення пухлин різних органів. Зростаюча проінформованість про потенційну шкоду консервантів для здоров'я сприяла проведенню досліджень ряду авторів

Представляються актуальними дослідження з обтрунтування рецептур і технології на фаршеву систему варених ковбасних виробів без нітриту натрію або калію.

Розглянуто питання можливості заміни нітриту натрію на використання нізину та кориці у виробнищтві варених ковбасних виробів.

Показано позитивний вплив ї харчової добавки (нізину та кориці) на терміни зберігання ковбасних виробів, а також на підвищення їх біологічної та харчової иінності Завдяки нізину та кориці відбувається здійснення біохімічних перетворень основних компонентів м'яса з утворенням з'єднань, щзо обумовлюють смак, аромат і консистенцію. Разом із изим відбуваються зміни фізико-хімічних параметрів м'ясного фариу в напрямку, несприятливому для розвитку патогенної мікрофлори. Нізин та кориия має антимікробні та антиоксидантні властивості, підвищує активність інсуліну в організмі людини. Крім того, слід зазначити, що кориия знижує в крові жир і холестерин та нейтралізує вільні радикали. Дослідники виявили, що кориия має властивість відновлювати чутливість тканин до інсуліну і контролювати иукор крові. Тому додавання до удосконаленої рецептури вареної діабетичної ковбаси вищого сорту нізину та кориці частково поповнює дефіцит мікроелементів за рахунок включення в раціон харчування людей як найбільш прийнятого харчового продукту для масового споживання-кориці

Ключові слова: нізин, коричя, харчові добавки, варені ковбаси, терміни зберігання, антимікробні та антиоксидантні властивості, мікроелементи, цукровий діабет.

\section{Использование низину в производстве вареных колбас функционального направления}

\author{
В.В. Власенко, И.Г. Власенко \\ vlasenkovanya@mail.ru
}

Винницкий торгово-экономический институт Киевского начионального торгово-экономического университета, ул. Соборная, 70, Винница, 21050, Украина

Citation:

Vlasenko, V.V., Vlasenko, I.G. (2016). Nizynu use in production cooked sausages funtsionalnoho direction. Scientific Messenger LNUVMBT named after S.Z. Gzhytskyj, 18, 2(68), 21-26. 
Сегодня на украинском рынке фигурирует более 300 наименований колбасных изделий, но большое внимание уделяется созданию новейших технологий производства пищевых продуктов, в частности продуктов, которые получили название функциональные продукты питания. Технологии производства функциональных вареных колбас Диабетическая предназначена для людей, страдающих сахарной болезнью (диабетом) и посвящена наша работа. При производстве вареньх колбас используют нитрит натрия или калия. По решению ВОЗ суточная доза для человека должен составлять не более 5 мг на 1 кг массы тела. Опасность использования нитритов заключается в том, что именно вторичные аминь способны реагировать с нитритами колбас, образуя нитрозамины. Нитрозамины относятся к сильнодействующим токсичных веществ, которые негативно влияют в первую очередь на печень и почки человека в результате чего происходит нарушение их функций и некрозы. Однако наибольиую опасность для организма человека составляет канцерогенное действие нитрозаминов, которые могут вызвать образование опухолей различных органов. Растущзая осведомленность о потенциальном вреде консервантов для здоровья способствовала проведению исследований ряда авторов. Представляются актуальными исследования по обоснованию рецептур и технологии на фариевого систему колбас без нитрита натрия или калия.

Рассмотрены вопросы возможности замены нитрита натрия на использование низину и корицы в производстве вареных колбасных изделий.

Показано положительное влияние й пищевой добавки (низину и корицы) на сроки хранения колбасных изделий, а также на повышение их биологической и пищевой ценности Благодаря низину и корицы происходит осуществления биохимических превращчений основных компонентов мяса с образованием соединений, обусловливаюших вкус, аромат и консистенцию. Вместе с этим происходят изменения физико-химических параметров мясного фариа в направлении, неблагоприятном для развития патогенной микрофлоры. Низин и корица обладает антимикробныли и антиоксидантными свойствами, повышает активность инсулина в организме человека. Кроме того, следует отметить, что корица снижает в крови жир и холестерин и нейтрализует свободные радикаль. Исследователи обнаружили, что корица имеет свойство восстанавливать чувствительность тканей к инсулину и контролировать сахар крови. Поэтому добавление к усовериенствованной рецептуры вареной диабетической колбасы высшего сорта низину и кориць частично восполняет дефицит микроэлементов за счет включения в рациион питания людей как наиболее принятого пищевого продукта для массового потреблениякорицьв

Ключевые слова: низин, корица, пищевые добавки, вареные колбасы, сроки хранения, антимикробные и антиоксидантные свойства, микроэлементы, сахарный диабет.

\title{
Nizynu use in production cooked sausages funtsionalnoho direction
}

\author{
V.V. Vlasenko, I.G. Vlasenko \\ vlasenkovanya@mail.ru
}

\begin{abstract}
Vinnitsa Trade and Economic Institute of Kyiv National University of Trade and Economics, Cathedral Str., 70, Vinnitsa, 21050, Ukraine
\end{abstract}

Today on the Ukrainian market appears more than 300 kinds of sausages, but focuses on the creation of new technologies in food production, including products that are called - functional foods. Technology production of functional cooked sausages Diabetic designed for people suffering from diabetes (diabetes) and consecrated our work. In the production of cooked sausages using sodium nitrite or potassium. By decision of the WHO daily intake for humans should be not more than $5 \mathrm{mg}$ per $1 \mathrm{~kg}$ of body weight. The danger of the use of nitrites lies in the fact that it is secondary amines can react with nitrites sausages to form nitrosamines. Nitrosamines related to the potent toxic substances, affecting primarily the liver and kidneys rights resulting in violations of their functions and necrosis. However, the greatest danger to the human body is carcinogenic effect of nitrosamines, which can cause the formation of tumors of various organs. The growing awareness of the potential dangers of preservatives health facilitated research into a number of authors. Presented current research study of recipes and technologies on system farshevu cooked sausage without nitrite, sodium or potassium. The question of the possibility of replacing the use of sodium nitrite nizynu and cinnamon in the production of cooked sausages.

Positive influence her food additives (nizynu and cinnamon) on the shelf life of sausages, as well as to enhance their biological and nutritional value Due nizynu and cinnamon implementation biochemical transformations is the main component of meat with the formation of compounds that contribute to flavor, aroma and consistency. At the same time there is a change of physical and chemical parameters of ground beef in a direction unfavorable to the development of pathogenic organisms. Nizyn and cinnamon has antibacterial and antioxidant properties, increases the activity of insulin in the body. Furthermore, it should be noted that cinnamon reduces blood fat and cholesterol and neutralize free radicals. The researchers found that cinnamon ability to restore sensitivity insulin and control blood sugar. So adding to improved diabetic recipes cooked sausage highest grade nizynu and cinnamon partially fills deficiency of trace elements to include in the diet people adopted as the food for mass consumption, cinnamon.

Key words: nizyn, cinnamon, food additives, cooked sausages, shelf life, antimicrobial and antioxidant properties, minerals, diabetes.

\section{Вступ}

На даний час варена ковбаса користується досить великим попитом у населення, за рахунок того, що має помірну ціну та високі смакові властивості. В сучасних умовах, підприємства України виготовляють понад 300 найменувань ковбасних виробів. При виробництві варених ковбас використовують нітрит на- трію або калію. За рішенням ВООЗ небезпека використання нітритів полягає в тім, що саме вторинні аміни здатні реагувати з нітритами ковбас, утворюючи нітрозаміни. Нітрозаміни відносяться до сильнодіючих токсичних речовин, які негативно впливають в першу чергу на печінку та нирки людини в результаті чого відбувається порушення їх функцій та некрози. Однак найбільшу небезпеку для організму людини стано- 
вить канцерогенна дія нітрозамінів, які можуть викликати утворення пухлин різних органів.

Представляються актуальними дослідження 3 обгрунтування рецептур і технології на фаршеву систему варених ковбасних виробів без нітриту натрію або калію. Зростаюча проінформованість про потенційну шкоду консервантів для здоров'я сприяла проведенню досліджень ряду авторів (Donchenko and Nadykta, 1999; Rogov et al., 2000; Alemasova et al., 2009; Bal'Prylypko, 2010; Vlasenko et al., 2012).

Важливе значення набуває створення виробів нового покоління, які мають загально зміцнюючу і профілактичну дію. Складові цих виробів здатні захистити організм від шкідливої дії оточуючого середовища і від появи в організмі людини патогенних мікробних клітин. Розробляються продукти з включенням мікроорганізмів, здатних синтезувати біологічно активні структури (антитіла, рецептори, гормони), які сприяють виведенню або розкладу і знищенню шкідливих комплексів, завдяки чому попереджається захворювання людини. Останнім часом значно зріс інтерес дослідників і виробників до нізину. Нізин (харчова добавка Е234) - пептидный антибіотик, що утворюється мікроорганізмом Streptococcus lactis. Цілеспрямоване використання нізину сприяє поліпшенню санітарно-мікробіологічних, органолептичних показників готового продукту, а також дозволяє інтенсифікувати виробничий процес. Завдяки нізину відбувається здійснення біохімічних перетворень основних компонентів м'яса 3 утворенням з'єднань, що обумовлюють смак, аромат і консистенцію. Разом із цим відбуваються зміни фізико-хімічних параметрів м'ясного фаршу в напрямку, несприятливому для розвитку патогенної мікрофлори.

Сьогодні велика увага приділяється створенню новітніх технологій виробництва харчових продуктів, зокрема продуктів 3 властивостями, які отримали назву - функціональні продукти харчування.

Метою наших досліджень було розробка удосконаленої рецептури вареної діабетичної ковбаси, без нітриту натрію та калію збагаченої нізином і корицею та вивчення впливу цих препаратів на якість готової продукції.

\section{Матеріал і методи досліджень}

3 метою визначення доцільності використання нізину та кориці в ковбасному виробництві були проведені дослідження в умовах ТОВ «Літинський м'ясокомбінат». 3 цією метою під час виготовлення вареної ковбаси «Діабетична» вищого сорту додавали нізин в кількості 10 г та кориці 100 г на 100 кг сировини. Готові ковбасні вироби піддавали фізикохімічним дослідженням за загально прийнятими методиками. Відбір проб проводили відповідно ГОСТ 9792-73. Всі реактиви, матеріали та середовища, що були задіяні в дослідах також відповідали вимогам ГОСТ. Визначення вмісту вологи - проводили шляхом висушування наважки до постійної маси при температурі $105{ }^{\circ} \mathrm{C}$ в сушильній шафі, $\mathrm{pH}$ готового виробу - колориметричним методом. Визначення вмісту хлористого натрію - проводили у водній витяжці з продукту методом Мора в нейтральному середовищі.

Оцінку органолептики ковбасних виробів проводили за дев'ятибальною шкалою у відповідності до методик. Дегустаційну оцінку проводили за дев'ятибальною шкалою.

Дослідження якісних показників ковбаси вареної «Діабетичної» вищого сорту з додаванням препарату нізину та кориці проводились згідно схеми (табл. 1).

Схема дослідження

\begin{tabular}{|c|l|l|}
\hline \multirow{2}{*}{ Вид ковбаси } & \multicolumn{1}{|c|}{ Зразки } \\
\cline { 2 - 3 } Варена «Діабетична» вищого сорту & \multicolumn{1}{|c|}{ контрольні } & \multicolumn{1}{|c|}{ дослідні } \\
\hline & $\begin{array}{l}\text { додатовлена згідно рецептури 3 } \\
\text { льноприйнята рецептура) }\end{array}$ & $\begin{array}{l}\text { Виготовлена згідно рецептури з додаванням } \\
\text { нізину - 10 г та кориці - 100 г на } 100 \text { кг } \\
\text { фаршу. }\end{array}$ \\
\hline
\end{tabular}

\section{Результати та їх обговорення}

Для вироблення ковбаси вареної «Діабетична» вищого сорту застосовували наступну сировину (включаючи м'ясну сировину, харчові інгредієнти, добавки, прянощі) і матеріали:

- яловичина жилованої вищого сорту з масовою часткою сполучної і жирової тканини не більше $3 \%$;

- телятина вищого сорту;

- свинина жилована вищого сорту;

- яйця курячі. Яйця курячі містять (на 100 г): ліпіди - 11,5 г, тригліцериди - 7,45, фосфоліпіди - 3,3 г, холестерина - 0,5 г, жирні кислоти - 9,26 г;

- масло. Масла виробляють пресуванням або екстракцією $з$ насіння олійних. Вміст жирних кислот в соняшниковій олії (у \%): стеаринова 1,6 - 4,6, пальмітинова $3,5-6,4$, міристинова до 0,1 , арахінова $0,7-0,9$, олеїнова 24 - 40, лінолева 46 - 62, ліноленова до 1;
- сіль кухонна. Залежно від способу виробництва та обробки сіль кухонна поділяється на дрібнокристалічну виварену; мелену, в тому числі різних видів (кам'яну, самоосадочну, осадочну) і різного діаметру помелу (несіяну і сіяну);

- нітрит натрію застосовували у вигляді розчину концентрацією не більше $2,5 \%$ в суворо регламентованих дозах відповідно до вимог нормативно технічної документації i під контролем ветеринарносанітарної служби підприємства, який формує і стабілізує колір, проявляє бактеріостатичну дію, а в дослідну партію вводили нізин 10 г та 100 г кориці на 100 кг фаршу, як бактеріцидну речовину;

- горіх мускатний запашний (лат. Myristica fragrans), має пекучо-пряний смак і своєрідний аромат;

- перець чорний - основна речовина, яка обумовлює смак перцю - алкалоїд пиперин; 
- молоко коров'яче пастеризоване з вмістом жиру 2,5 і 3,2\%. Білки молока володіють високою поживною цінністю, що обумовлено не тільки їх доброю засвоюваністю (до 96\%), але і амінокислотним складом. Вони є повноцінними, так як в них містяться незамінні амінокислоти.
Зразки дослідних варених ковбас виробляли відповідно до технологічної схеми (рис. 1).

Рецептури вареної ковбаси «Діабетична» вищого сорту наведена у табл.2.

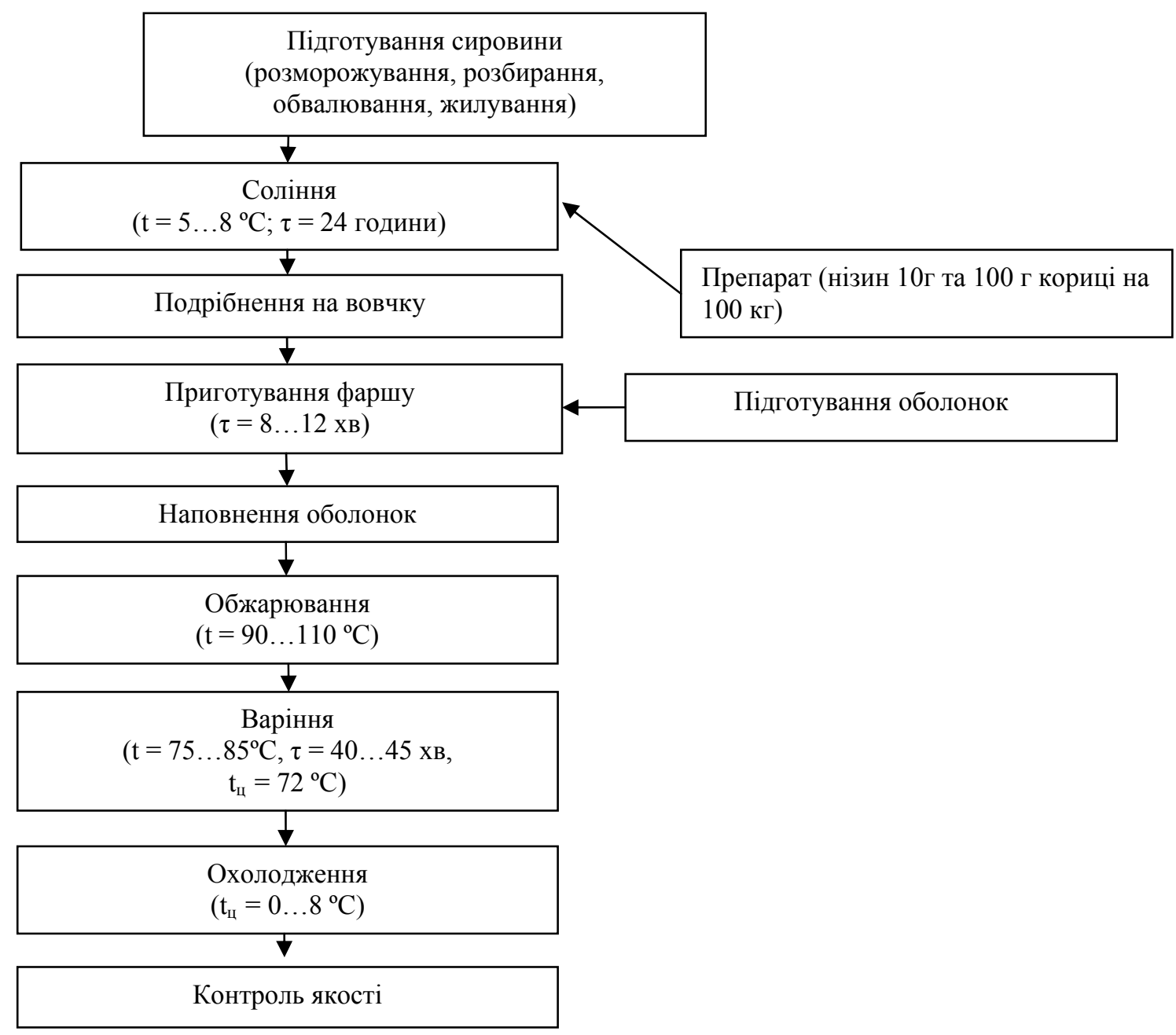

Рис. 1. Технологічна схема виробництва варених ковбас «Діабетична» без нітриту натрію та збагачена нізином і корицею

Рецептури ковбаси вареної «Діабетична»

\begin{tabular}{|c|c|c|}
\hline \multirow[t]{2}{*}{ Сировина } & \multicolumn{2}{|c|}{ Зразки } \\
\hline & контрольний & дослідний \\
\hline яловичина жилована вищого сорту, кг: & 20 & 20 \\
\hline телятина вищого сорту & 20 & 20 \\
\hline свинина жилована вищого сорту & 55 & 55 \\
\hline яйця курячі & 2 & 2 \\
\hline масло солодковершкове & 3 & 3 \\
\hline Всього & 100 & 100 \\
\hline \multicolumn{3}{|l|}{ Прянощі та матеріали, г: } \\
\hline сіль кухонна харчова & 2375 & 2375 \\
\hline нізин & - & 10 \\
\hline кориця мелена & & 100 \\
\hline нітрит натрію & 7 & - \\
\hline горіх мускатний & \multicolumn{2}{|c|}{50} \\
\hline перець чорний або білий мелений & \multicolumn{2}{|c|}{60} \\
\hline молоко коров'яче пастеризоване із вмістом жиру 2,5 и 3,2 \% & \multicolumn{2}{|c|}{15} \\
\hline
\end{tabular}


Кориця має антимікробні та антиоксидантні властивості, підвищує активність інсуліну в організмі людини. Крім того, слід зазначити, що кориця знижує в крові жир і холестерин та нейтралізує вільні радикали. Дослідники виявили, що кориця має властивість відновлювати чутливість тканин до інсуліну і контролювати цукор крові.

Відповідні аналізи на наявність санітарнопоказових мікроорганізмів у варених ковбасах (табл. $3,4)$ свідчать про безпечність даних зразків.

Органолептична оцінка варених ковбас при зберіганні $(\mathrm{n}=3, \mathrm{P} \geq 95)$

\begin{tabular}{|c|c|c|c|c|}
\hline \multirow{3}{*}{$\begin{array}{c}\text { Назва } \\
\text { показника }\end{array}$} & \multicolumn{4}{|c|}{ Зразки при зберіганні, діб } \\
\hline & 3 & 6 & 3 & 6 \\
\hline & \multicolumn{2}{|c|}{ контрольний } & \multicolumn{2}{|c|}{ дослідний } \\
\hline Зовнішній вигляд & 9,0 & 8,0 & 9,0 & 8,0 \\
\hline Вигляд на розрізі & 9,0 & 8,0 & 9,0 & 8,0 \\
\hline Колір & 9,0 & 7,0 & 9,0 & 8,0 \\
\hline Консистенція & 9,0 & 7,0 & 9,0 & 8,0 \\
\hline Запах, смак & 9,0 & 7,0 & 9,0 & 7,0 \\
\hline Загальна оцінка, бал & 9,0 & 7,4 & 9,0 & 7,8 \\
\hline
\end{tabular}

Якісний склад мікрофлори при зберіганні варених ковбас (n = 3, P $\geq 95)$

Табличя 4

\begin{tabular}{|l|c|c|c|c|}
\hline \multirow{2}{*}{$\begin{array}{c}\text { Санітарно-показові } \\
\text { мікроорганізми }\end{array}$} & \multicolumn{3}{|c|}{ Зразки при зберіганні, діб } \\
\cline { 2 - 5 } & 3 & 6 & \multicolumn{2}{|c|}{3} \\
\hline БГКП, в 1 г продукту & \multicolumn{2}{|c|}{ контрольний } & не виділені & не виділені \\
\hline $\begin{array}{l}\text { Бактерії роду Salmonella, в 25 г виділені } \\
\text { продукту }\end{array}$ & не виділені & не виділені & не виділені \\
\hline $\begin{array}{l}\text { Сульфітредукуючи клостридії, в } \\
0,01 \text { г продукту }\end{array}$ & не виділені & не виділені & не виділені \\
\hline
\end{tabular}

Про зміну кількісного складу мікрофлори ковбас судили по зростанню кількості мезофільних аеробних та факультативно-анаеробних мікроорганізмів упродовж зберігання, що наведено на рис. 2.

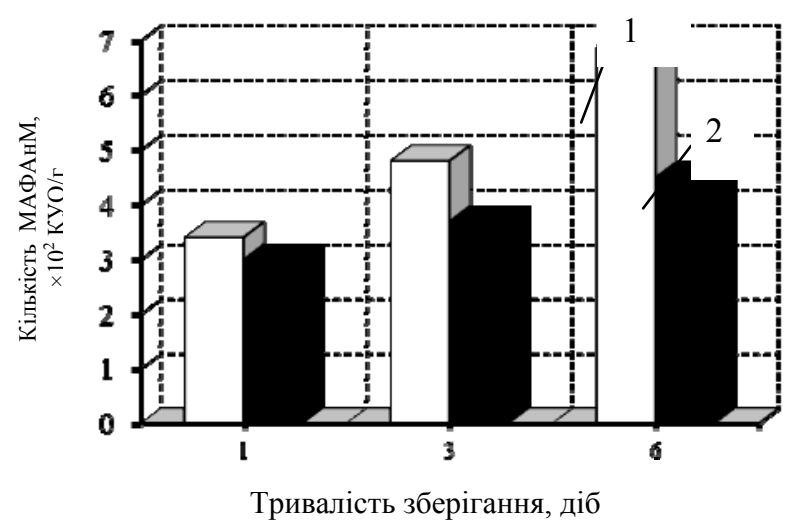

Рис. 2. Залежність розвитку МАФАнМ від тривалості зберігання варених ковбас:

1 - контроль; 2 - дослідний зразок

Показник КМАФАнМ дослідного зразку через 6 діб не перевищував вимоги стандарту, тобто мав значення нижчі за $1 \times 10^{3} \mathrm{KУО} / г$ продукту. Варені ковбаси, вироблені за новою технологією, мають більш задовільний бактеріальний стан. Погіршення смакових властивостей ковбас при зберіганні чиниться насамперед в результаті псування жиру. Враховуючи, що нітрит натрію володіє антиокислювальною дією, то зниження його вмісту може викликати окислюва- льне псування. Тому доцільно було провести органолептичні дослідження.

Варені ковбаси мають різні харчові і смакові властивості, які залежать не лише від виду самого продукту, технології виготовлення, але й від використання сировини. Зокрема, дослідні зразки вареної ковбаси, до рецептури фаршу до яких було внесено нізин та корицю, згідно рецептури не змінювали органолептичні показники якості порівняно 3 контролем. Вони характеризувалися високими смаковими якостями, пружною консистенцією, без сторонніх запахів та присмаків. Батони на розрізі були світло-коричневого кольору, фарш рівномірно перемішаний без сірих плям і порожнин (табл. 5).

Органолептичне оцінювання якості й безпеки харчових продуктів починають 3 використання візуального методу, який грунтується на сприйнятті зовнішнього вигляду і забарвлення харчових продуктів. Зовнішній вигляд - це комплексний показник, який включає форму, забарвлення, стан поверхні та ï цілісність. За допомогою органу зору людина одержує найповнішу інформацію про якість продуктів (до 70 80\% загальної інформації).

На основі проведених досліджень встановлено, що батони вареної ковбаси «Діабетична» вищого сорту, як дослідних, так і контрольних зразків, були сухими, чистими поверхня без пошкоджень оболонки, набряків фаршів, залипів.

Для отримання більш точних результатів дослідження якості варених ковбасних виробів, була проведена дегустаційна оцінка із залученням п'ятьох дегустаторів. 
Органолептична оцінка варених ковбас

\begin{tabular}{|l|l|c|l|l|}
\hline \multirow{2}{*}{ Зразок } & \multicolumn{4}{|c|}{ Характеристики } \\
\cline { 2 - 5 } & \multicolumn{1}{|c|}{ зовнішній вигляд } & консистенція & \multicolumn{1}{|c|}{ вигляд фаршу на розрізі } & \multicolumn{1}{c|}{ запах та смак } \\
\hline контрольний & $\begin{array}{l}\text { Батони 3 сухою, чистою } \\
\text { поверхнею без пошкоджень } \\
\text { оболонки, набряків фаршів, } \\
\text { залипів. }\end{array}$ & Пружна & $\begin{array}{l}\text { Від рожевого до світло- } \\
\text { рожевого кольору, рівномі- } \\
\text { рно перемішаний без сірих } \\
\text { плям і порожнин. }\end{array}$ & $\begin{array}{l}\text { Властивий даному смаку } 3 \\
\text { ароматом прянощів, вміру } \\
\text { солоний, без стороннього } \\
\text { присмаку та запаху. }\end{array}$ \\
\hline дослідний & $\begin{array}{l}\text { Батони 3 сухою, чистою } \\
\text { поверхнею без пошкоджень } \\
\text { оболонки, набряків фаршів, } \\
\text { залипів. }\end{array}$ & Пружна & $\begin{array}{l}\text { Від рожевого до світло- } \\
\text { рожевого кольору, рівномі- } \\
\text { рно перемішаний без сірих } \\
\text { плям і порожнин. }\end{array}$ & $\begin{array}{l}\text { Власий даному смаку } 3 \\
\text { солоний, без стороннього } \\
\text { присмаку та запаху. }\end{array}$ \\
\hline
\end{tabular}

Дегустаційна оцінка варених ковбас проводилась по дев'ятибальній системі згідно шкали балової оцінки (ГОСТ 9959-91) по наступним показникам: зовнішній вигляд, малюнок на розрізі, колір, запах, смак, соковитість, консистенція (табл. 6).

Отже, з табл. 6 видно, що дослідні зразки ковбаси вареної діабетичної не поступились контрольним зразкам. Слід зазначити що набрана кількість балів відповідає дуже добрій якості. Використання у складі компонентних харчових систем нізину та кориці забезпечує отримання стабільних якісних характеристик готових виробів. Антибактеріальні властивості кориці досить сильні, вона вважається екстенсивною консервуючою речовиною (фенольний коефіцієнт 7,8). Запобігає поширенню інфекції (мікроорганізмів), продовжує термін реалізації продукції.

Таблиия 6

Загальна середня оцінка якості варених ковбас по дев'ятибальній системі

\begin{tabular}{|c|c|c|c|c|c|c|c|c|}
\hline \multirow[b]{2}{*}{ Зразки } & \multicolumn{7}{|c|}{ Оцінка ковбаси по дев'ятибальній системі } & \multirow[b]{2}{*}{$\begin{array}{c}\text { Загальна сере- } \\
\text { дня оцінка } \\
\text { якості }\end{array}$} \\
\hline & 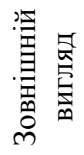 & 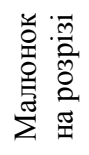 & 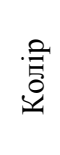 & $\begin{array}{l}\text { 胥 } \\
\text { 壳 } \\
\text { m }\end{array}$ & 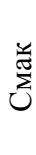 & 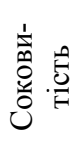 & 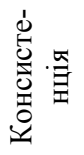 & \\
\hline Контрольні & 8,8 & 8,7 & 8,3 & 8,8 & 9 & 8,4 & 8,5 & 60,5 \\
\hline Дослідні & 8,8 & 8,6 & 8,2 & 9,0 & 9 & 8,4 & 8,6 & 60,6 \\
\hline
\end{tabular}

\section{Висновки}

Виходячи $з$ отриманих результатів досліджень та аналізу доступних наукових даних, можна зробити висновок, що використання нізину та кориці як природного консерванту при виробництві варених ковбасних виробів, дає можливість подовжити термін зберігання даних харчових продуктів, а також покращити їх харчову та біологічну цінність. Кориця має властивість відновлювати чутливість тканин до інсуліну і контролювати рівень цукру в крові людей хворих на цукровий діабет та дозволяє запровадити технологію виробництва вареної ковбаси без використання нітриту натрію або калію, замінивши його нізином та корицею, які мають хороші бактеріцидні та пробіотичні властивості.

Перспективи подальших досліджень. Використання нізину та кориці не потребує додаткових дзволів санітарної служби, так як кориця входить до списку харчових добавок, що дозволені для використання у харчовій промисловості в Україні, який затверджений Постановою № 12 КМУ. Запровадження нізин та кориці в технологію виробництва м'ясних продуктів харчування, що швидко псуються покращує смакові якості продукту та підвищує термін реалізації в торгові мережі.

\section{Список використаної літератури}

Alemasova, A.S., Holodova, O.Ju., Molokanova, L.V. (2009). Vyznachennja kontaminantiv kovbasy varenoi' «Donec'ka» za dopomogoju himichnyh metodiv. Suchasni problemy ta naprjamky vykladannja himichnyh dyscyplin pry pidgotovci konkurentozdatnyh fahivciv: mater. region. nauk.metod. seminar. Donec'k: DonNU. 25-28 (in Ukrainian).

Donchenko, L.V., Nadykta, V.D. (1999). Bezopasnost' pishhevogo syr'ja i produktov pitanija. M.: Pishhevaja prom-st' (in Russian).

Bal'-Prylypko, L.V. (2010). Tehnologija zberigannja, konservuvannja ta pererobky m'jasa: pidruchnyk (in Ukrainian).

Vlasenko, V.V., Tonkopij, S.A., Vlasenko, I.G. (2012). Vykorystannja laktokokiv z vysokoju proteolitychnoju vlastyvistju u ptahivnyctvi ta harchovij promyslovosti. Zbirnyk naukovyh prac' VNAU. 4(62), 171-175 (in Ukrainian).

Rogov, I.A., Zabashta, A.G., Kazjulin, G.P. (2000). Obshhaja tehnologija mjasa i mjasoproduktov. M.: Kolos (in Russian).

Стаття надійшла до редакції 15.09.2016 